\title{
Logistics Space: A Literature Review from the Sustainability Perspective
}

\author{
Meiling $\mathrm{He}^{1, *} \mathbb{C D}^{\mathbb{D}}$, Jiaren Shen ${ }^{1}$, Xiaohui $\mathrm{Wu}^{1}$ and Jianqiang Luo ${ }^{2}$ \\ 1 School of Automobile and Traffic Engineering, Jiangsu University, Zhenjiang 212013, China; \\ shenjiarenujs@163.com (J.S.); wuxiaohui@ujs.edu.cn (X.W.) \\ 2 School of Management, Jiangsu University, Zhenjiang 212013, China; luojianqiang@ujs.edu.cn \\ * Correspondence: hemeiling@ujs.edu.cn
}

Received: 5 July 2018; Accepted: 5 August 2018; Published: 8 August 2018

\begin{abstract}
The acceleration of economic globalization and integration has led to a dramatic increase in the flow of goods worldwide and changes in the spatial location of logistics facilities. The location of logistics facilities affects not only the cost and efficiency of cargo transportation activities, but also the rational allocation of logistics resources. Recently, the two major perspectives of logistics space research-cluster (the concentration of logistics facilities and functions in geography) and sprawl (movement of facilities from the urban core to peripheral places) have received extensive attention from academia and policy makers. The evolution of logistics space is influenced by land prices, traffic accessibility, market demand, agglomeration advantages and government policies. The purpose of this study is to present a literature review of logistics space, including data sources, research methods as well as research theories, and to study the impact of logistics space from the perspective of sustainable development. The research results provide some reference for logistics space researchers and logistics facility planners, and play a role in formulating new logistics development strategies and promoting the sustainable development of logistics.
\end{abstract}

Keywords: logistics space; sprawl; cluster; influencing factors; sustainability

\section{Introduction}

Under the background of economic globalization and regional economic integration, increasingly products are circulating, producing, selling and consuming around the world. Logistics, as the new engine of economic growth, plays a core role in overcoming the constraints of time-space between producers and the markets they serve. Logistics is the physical flow of goods from the place of supply to the receiving place. According to actual needs, the basic functions of transportation, storage, loading and unloading, handling, packaging, distribution processing, distribution, recycling, and information processing are organically combined. Industrial space refers to the economic phenomenon in which a certain industry combines spatial distribution and industry within a country or region. Logistics space is a kind of industrial space, which refers to the projection of urban logistics activities (professional markets, logistics companies, logistics nodes, logistics infrastructure) in the geographical space [1]. In order to speed up urbanization, the government blindly planned a large number of logistics facilities. On the one hand, this has intensified the increasingly prominent contradiction of urban land use, and on the other hand caused the waste of logistics resources.

The spatial layout and evolution of urban logistics facilities is an important force driving urban economic and spatial development. Data from large cargo surveys in the Tokyo metropolitan area show that the integration of logistics facilities has increased the efficiency of logistics and transportation by $4 \%$ [2]. The spatial concentration of logistics companies promotes the improvement of cooperation and value-added services between enterprises [3]. Research from the perspective of geography mainly 
includes the distribution law and influencing factors of logistics space. Brown studies the distribution of storage facilities in the United States from a geographical perspective, and found that the accessibility of air and road transport networks strongly influenced the location of storage sites [4]. Sakai analyzes the locational dynamics of logistics facilities in the Tokyo metropolitan area, and found that logistics facilities moved outward by $26 \%$ in only 10 years [5]. In addition, Gothenburg, Atlanta, Zurich, and other places also showed the phenomenon of logistics sprawl [6-8]. Dablanc analyzes two important characteristics of logistics industry geography: logistics sprawl and polarization logistics activities. Logistics sprawl has led to changes in the geographical location of urban cargo, increased mileage and corresponding emissions of trucks, and affected the commuting of logistics employment [9].

Land availability and its costs, transportation infrastructure and government policies are important factors influencing the evolution of logistics space. Giuliano divides the factors that affecting the spatial dynamics of the California logistics industry into economic development policies, metropolitan size, economic structure and physical geography [10]. Holl studies the impact of accessibility on the location of logistics companies, while Aljohani explains the reasons for the relocation of logistics facilities from land use and freight exclusion $[9,11]$. Kumar finds that transportation infrastructure has a positive impact on transportation and logistics clusters [12]. By studying the traditional disciplines of logistics, economics and transportation science have no in-depth research on logistics space, and logistics is still relatively undeveloped from the perspective of geography [13]. Logistics space as an important part of the industrial space, some scholars study the spatial aggregation and distribution of the logistics industry from the industrial space [14]. More scholars have examined the spatial patterns of logistics activities and related planning policy issues based on case studies [8].

The constant increase of logistics demand has put forward higher requirements for the development of modern logistics. The quantity and types of logistics facilities and enterprises have increased dramatically, and the quality of logistics services has being increasing, which has led to dramatic changes in the spatial distribution of logistics [15]. Restructuring of logistics space leads to geographical dispersion of supply chain, increasing the distance between suppliers, manufacturers, distributors and consumers [16]. The evolution of logistics space is increasingly important for the sustainable development of logistics in terms of environmental efficiency, social efficiency and economic efficiency. Therefore, grasping the spatial distribution of logistics activities, clarifying the location characteristics and forming mechanism of logistics space have become a realistic problem facing logistics development.

It has been observed that although there are a large number of empirical studies on the distribution and evolution of urban logistics space, the literature review on logistics space and influencing factors has not been resolved. In-depth study of the evolution of logistics space has importantly guiding significance for rational allocation of urban logistics resources and coordination of logistics and economic development. This paper examines academic literature, analyzes changes in spatial patterns of logistics activities, and considers possible explanations for observed spatial changes.

The structure of the paper is as follows: In order to understand the evolution of logistics space better, Section 2 explains the definition, activities and influencing factors of logistics space to better understand the existence and importance of logistics space. Section 3 presents the systematic literature review and describes search strategy as well as the outcomes of the review. The impact of logistics space on sustainability is discussed in Section 4 along with three dimensions of sustainability in the paper. Section 5 provides a discussion of logistics space. The last section gives the summative conclusions of the paper and points to potential research areas.

\section{Logistics Space}

\subsection{Components of Logistics Space}

Urban logistics is an organic system composed of logistics enterprise, logistics nodes and logistics infrastructure. Logistics enterprise, as the economic organization of logistics activities, undertakes 
basic functions such as transportation, storage, loading and unloading, packaging, distribution processing and distribution. The logistics node is the spatial main body that undertakes the city logistics function, including the logistics park, the logistics center, and the distribution center. The integrated transportation network is the basis for the operation of the entire social logistics system, such as: railways, highways, airports, ports and other infrastructure. The logistics practitioners are the implementers of logistics activities. The spatial density distribution of logistics employees can reflect the regional scope and frequency of logistics activities. The industry generates a large amount of logistics demand and is interdependent with the logistics industry in space. Therefore, from the perspective of industry to study the spatial distribution of logistics demand, we can also analyze the changes in logistics space. Therefore, this paper holds that logistics space is a space system composed of logistics enterprise, logistics nodes, logistics infrastructure and industry.

\subsection{The Influencing Factors of the Evolution of Logistics Space}

\subsubsection{Land Price}

Logistics is the process of strategically managing the storage and movement of materials, parts and finished inventory [17]. Logistical activities of storage, freight transport require substantial amounts of land. Logistics land involves distribution, logistics and warehouse (DLW), mainly includes storage land, land for external traffic and land for public facilities, of which warehousing has the greatest demand for land [18]. From 2003 to 2013, the number of storage facilities in the United States increased by $15 \%$ [10]. Other metropolises, such as Toronto, Zurich and Atlanta, have seen their warehouses grow rapidly $[7,8,19]$. The demand for logistics land in some developing countries is also increasing. For example, the growth rate of storage area in Jiangsu Province of China is 6.1\% [20]. However, Sakai finds that the logistics facilities that are $400 \mathrm{~m}^{2}$ or smaller in floor area dropped from 43 to $29 \%$, and the share of the facilities that are larger than $3000 \mathrm{~m}^{2}$ increased by $12.1 \%[5,21]$. The number of logistics facilities is declining, but the average size is steadily increasing [21]. It means that logistics facilities are developing professionally and the demand for land size is larger. Different logistics facilities have different requirements for land size. The average size of parcel service terminals is 5000 square meters, while the average size of large retailers' warehouses is as large as 100,000 square meters, which can only be met in the suburbs [22]. The improvement of storage technology has improved the efficiency of land utilization. To a certain extent, it has eased the demand for warehouses land (e.g., High-bay warehouses and warehouse management systems (WMS)) [23,24]. However, the overall demand for logistics-related land is likely to increase significantly by the replacement of other logistics activities, such as inter-modal transshipment, goods handling, outdoor storage and vehicle parking [23]. With the competition and development, all walks of life are constantly expanding and strive for the best interests. Rising competition in the location has led to accelerated land consumption [21]. Logistics land is related to the internal structure of the city, most of the research focuses on monocentric systems with a concentric structure. According to Burgess's theory of concentric circles, with the increase of urban population and the expansion of urban areas, each inner zone inevitably extends outward and invades the adjacent outer belt, thus creating a succession of land use [25]. This succession will aggravate the conflict between freight-related activities and other land uses for the same land and interfere with each other [9]. Air pollution, noise and traffic congestion will have a negative impact on the living environment and force freight-related activities to move away from the mixed area of residential and industrial [26,27]. Changes in the structure of urban interior space (from industrial land to non-industrial land) and industrial land use control have contributed significantly to the growth of land price. Land cost is an important part of operating costs of industrial enterprises, which affects the enterprise location, industrial sprawl and the industrial layout [28]. Logistics sprawl is more affected by land prices than other industrial sprawl, and logistics enterprises will have more consideration of land prices in the choice of location [29,30]. In general, there is a growing demand for logistics-related land, while fewer and fewer land is available. The conflict between demand and supply will make 
land play increasingly important role in the location of logistics facilities and the movement of logistics spatial. Land price makes logistics enterprises away from the city center, which increases the distance of freight transportation. Urban planners need to develop a rational strategy for the use of sustainable cargo land to ensure the future movement of freight and logistics facilities within the urban interior [9].

\subsubsection{Traffic Accessibility}

Traffic accessibility refers to the size of the opportunities for interaction between nodes in a traffic network, which reflects the degree of traffic convenience and location advantages of a region [31]. The key determinant of transport accessibility is the capacity and structure of transport infrastructure, which stimulates the movement of goods, reduces transit times, improves market access and promotes economic growth [32-34]. For logistics enterprises, the transportation of goods is at the core of their business, so accessibility plays a major role in the location decision. Highly accessible areas attract more logistics employment and logistics enterprises [35]. As production becomes increasingly dispersed, China's cargo turnover has increased by 110\% from 2006 to 2016. The increase of shipping distances and fuel prices has forced logistics enterprises to consider escalating shipping costs. The negative impact of logistics activities on the environment is expanding and there is a certain spatial aggregation effect [36]. Access to motorway, port and other transport infrastructures can increase transport efficiency and reduce transportation costs. Verhetsel calculates the time or distance of 235 logistics sites to the freeway intersection, rail terminal, inland navigation terminal and seaport, respectively as road accessibility, rail accessibility, inland navigation accessibility, and through discrete choice modeling revealed that access to port, motorway and a rail terminal play no significant role in the location choice of logistics enterprises [30]. Bowen finds that highway accessibility is more important than and sea and railway accessibility by analyzing the relationship between the location of warehouses and accessibility measures of several kinds of transport networks in the US [4]. Compared to other enterprises (manufacturing, business services, and even transporters), logistics enterprises are closer to highways and other transport infrastructure. This confirms that the logistics enterprises are market-oriented and need to be located in or close to the consumer market [11]. Accessibility is strongly and significantly correlated with the spatial distribution and evolution of logistics enterprises. For example, the logistics cluster in the United States is mainly located near major airports and seaports, while the logistics facilities in The Netherlands are relatively often at multimodal terminals $[37,38]$. Land near major roads, ports and other transport infrastructure is relatively expensive compared to the surrounding areas [2]. So, logistics enterprises need to consider the relationship between accessibility and rent in the site selection. Accessibility is an important factor in the location of logistics enterprises, which affects transport efficiency and service quality of logistics enterprises.

\subsubsection{Market Demand}

Logistics as a service industry, near the market can get a lot of logistics demand. Changes in the logistics space follow those in the market, and the expansion of logistics has always followed that of the population and other commercial institutions $[5,8]$. In addition, the large demand for logistics in ports, airports, and industrial parks is an important factor in attracting logistics accumulation. Manufacturing industry is the basis for logistics development. In 2016, China's industrial product logistics accounted for $93.16 \%$ of total social logistics. At the same time, the development of manufacturing industry should also be supported by logistics industry, and the logistics link accounts for more than $90 \%$ of all production processes [39]. Manufacturing companies provide a lot of market demand, while logistics companies provide efficient logistics services. The coordinated development of the logistics industry and manufacturing industry is an objective requirement to reduce the cost of production enterprises and promote the development of logistics enterprises. The balance between logistics supply and logistics demand drives the evolution of logistics space. Therefore, it is necessary for the government to use the demand forecasting model to forecast and evaluate logistics requirements when planning logistics nodes and corporate decision makers in deciding company site selection [40]. Some 
logistics parks do not take into account the role of the market when planning, leaving these logistics parks idle. Land cost and transportation accessibility affect the operating costs of logistics facilities or logistics enterprises, and the market determines the future development and economic benefits of logistics enterprises.

\subsubsection{Agglomeration Advantage}

Enterprises in the site selection, in order to obtain a better environment for development, often choose to locate in the industrial agglomeration area. Heuvel illustrates the agglomeration advantages of logistics enterprises based on three sources of Marshall's agglomeration economies: namely labor market (specialized labor); inputs sharing (combining transport flows, reducing transportation costs and promoting the development of multimodal transport services) and knowledge spillovers (learning and cooperation between enterprises) [38]. Rivera divides the benefits of logistics agglomeration into: the sharing of physical assets, the sharing of production factors and the strategic alliances of existing facilities and value-added services, and concludes that the logistics cluster improves the efficiency of global supply chain and reduces the cost, improve the basic transportation network [3,37]. Porter's "Diamond Model": Industrial agglomeration is the result of competition, which is conducive to industrial competitiveness and national competitiveness. Based on Porter's diamond model, Chung evaluated the competitiveness of major Asian logistics clusters [41]. Transportation costs, service and other advantages attract logistics enterprises to join the cluster [42]. In addition, as a producer service industry, the logistics industry needs to be the target of service around its agglomeration area. Logistics industry is demand-oriented, that is, the logistics industry is in spatial connection with other industries. Logistics enterprises in order to obtain a larger market share, will take the initiative to focus on the concentration of related industries. The coordinated development of manufacturing and logistics is an objective requirement for reducing manufacturing costs and accelerating the development of logistics enterprises. The negative externalities of agglomeration, such as the rising prices of land and labor and the congestion of transport roads, will also reduce the agglomeration advantages and thus remove the agglomeration area [37]. For logistics enterprises, the agglomeration area provides sufficient professional labor force, transportation advantages, resource sharing, value-added services and perfect infrastructure for logistics enterprises. In addition, the government promotes logistics agglomeration through various financial incentives and tax incentives.

\subsubsection{Government Policy}

With the rising status of logistics in social and economic development, countries have begun to use logistics as the artery and basic industry for the development of the national economy. The government can inspire and guide the distribution intention of logistics enterprises and guide the relocation of logistics enterprises through pre-launching of city plans and public government information [43]. In forming a logistics space location, the government can control rent and availability by changing traffic conditions, such as re-planning transportation routes and cargo terminal locations, and by increasing or decreasing logistics land use [44]. Land use planning and pricing can be used by the government to control the sprawl of logistics [2], and can also be used to stimulate spatial concentration of logistics enterprises [45]. For example, China has increased its support for land and other policies, implemented and improved land-use policies that support the development of the logistics industry, and supply logistics land according to law. It also identified 29 first-level logistics park layout cities and 70 second-level logistics park layout cities. Through the advantages of facilities and agglomeration effects of logistics parks, logistics enterprises are guided to focus on parks, resources are shared, and logistics organization efficiency is improved. The government can also improve the effectiveness of logistics clusters by providing comprehensive infrastructure, effective administrative procedures, and increased training of employees [3]. In addition, the government promotes energy conservation and emission reduction in the transportation industry by establishing a logistics information platform, formulating tax policies and fuel economy standards, and ensuring the sustainable development of 
logistics [46]. The logistics industry has made great contributions to promoting circular economy [47]. The government can rationally allocate logistics resources through macro regulation and control, and avoid the uncoordinated regional logistics and economic development. The distribution of logistics parks and logistics centers is often guided by the government. The positioning of logistics enterprises is also affected by local policies. In addition, some places tend to adopt preferential policies to attract foreign logistics enterprises [48].

\subsection{The Activities of Logistics Space}

\subsubsection{Logistics Sprawl}

With the suburbanization of cities and population, the logistics sprawl gradually appears in the urban development of various countries. Logistics sprawl, the spatial deconcentration of logistics facilities and distribution centers [49], is the trend of outward movement of logistics facilities from inner urban areas to suburban and exurban areas. "Logistics polarization" and "logistics suburbanization" are also used to describe the phenomenon of logistics facilities from the inner city to the suburbs [50]. Land cost is the most important factor contributing to the location of logistics facilities [29]. Logistics land-use spatial structure and the mechanism of its evolution have always been the key issues for logistics land use and logistics sprawl. Numerous studies of logistics land-use spatial structure involve geography, economics, sociology, and other fields. The next most important factor is traffic accessibility. Logistics facilities are located closer to highways and other transport infrastructure compared to other sectors. In inner urban areas, traffic is congested, and logistics facilities are also locating increasingly in suburban locations [11]. The suburbs provide cheaper industrial land and easier access to road, rail as well as air transport for logistics facilities. Those factors have led to the movement of logistics facilities away from urban centers and a large number of studies of logistics sprawl have verified the movement (e.g., Gothenburg, Atlanta, Zurich, Los Angeles, and Tokyo).

Most researches judge the logistics sprawl by the change in the average distance of logistics facilities from the urban center. Table 1 shows the increased distance in Gothenburg, Atlanta, Los Angeles, Tokyo, Zurich and Toronto respectively [5-8,10,19,51]. However, the increase in distance does not justify logistics sprawl as the entire city is expanding. So, Dablanc and Ross compared the changes in the average distance of logistics facilities against that of business establishments $(4.5 \mathrm{~km}$ versus $2.1 \mathrm{~km}$ ), they called "relative (logistics) sprawl". Sakai also finds that the average distance of the logistics facilities from the urban center has increased considerably more than that of the population ( $2.4 \mathrm{~km}$ versus $0.4 \mathrm{~km}$ ). Giuliana finds logistics facilities in Los Angeles and San Francisco shift to places with low employment density [10]. Woudsma divides Toronto into three areas: The Greater Toronto Area (GTA), the Greater Golden Horseshoe (GGH) and Southern Ontario (S.ON). He compares the movement of warehouses with all businesses and finds that warehouses are not only sprawling within the core urban area, but also the exurban area that includes satellite communities within the economic sphere of the city [19]. Comparing the sprawl patterns of warehouses with all businesses is useful to determine whether warehouses are sprawling at the same rate as the urban area. The other method to determine logistics sprawl is analyzing the number or density of logistics facilities. Cidell finds that the number of warehousing establishments grew faster in the suburban counties than that in the central counterparts by analyzing the locations of warehousing establishments of the fifty largest metropolitan areas in the US during 1986-2005 [52]. The warehouse as a place to store goods, which is the largest demand for land in all logistics activities, and warehousing sprawl is more obvious than that of other logistics activities [7]. This is why many studies have used storage facilities as research objects. Heitz compares the Paris region of France with the Randstad area of Dutch and analyzes the differences in the distribution of logistics between monocentric region and polycentric region, and finds that the urban structure affects the logistics sprawl [50]. 
Table 1. The increased distance of logistics sprawl.

\begin{tabular}{|c|c|c|c|c|}
\hline Lead Author & Location & Period & Increased Distance & References \\
\hline Heitz & Gothenburg & 2002-2014 & Logistics facilities $(+4.2 \mathrm{~km})$ & [6] \\
\hline Giuliano & Los Angeles & $2003-2013$ & Warehousing and distribution $(+5.6 \mathrm{~km})$ & [10] \\
\hline Dablanc & Atlanta & $1998-2008$ & Warehouse $(+4.2 \mathrm{~km})$ & [8] \\
\hline Dablanc & Los Angeles & 1998-2009 & Warehouse (+6.1 km) & {$[51]$} \\
\hline Sakai & Tokyo & $2003-2013$ & Logistics facilities $(+6.6 \mathrm{~km})$ & [5] \\
\hline Todesco & Zurich & 1995-2012 & $\begin{array}{c}\text { Warehouse }(+9.5 \mathrm{~km}) \\
\text { Parcel service }(+7.7 \mathrm{~km})\end{array}$ & [7] \\
\hline Woudsma & Toronto & 2002-2012 & $\begin{array}{l}\text { Warehouse (GTA: }+1.3 \mathrm{~km} \text {, GGH: } \\
\quad+9.5 \mathrm{~km}, \text { S.ON: }+29.5 \mathrm{~km})\end{array}$ & [19] \\
\hline
\end{tabular}

\subsubsection{Logistics Cluster}

Clustering is a common phenomenon in the process of industrial development. From manufacture to service, industrial clusters of various industries play a very important guiding and promoting role in industrial development and economic development. For this special economic phenomenon, the research of scholars from Marshall, Weber, Michael Porter, Krugman and other scholars has gradually elevated the status of industrial clusters in economic history. Rivera and Sheffi define a logistics cluster as the geographic concentration of third-party logistics (3PL-s), transport carriers, storage providers, and freight forwarders that provide logistics services [37]. The main cause of the logistics space agglomeration is external scale economy, market demand and government policy guidance. The advantages of economies of scale lie in the ability to integrate resources, share infrastructure, and build a specialized labor market. Logistics cluster creates positively impacts both in terms of transportation capacity sharing and resource sharing, as well as the provision of value added services [3]. The most apparent benefit for logistics clusters is that it is combining transport flows, which often saves transport costs. Moreover, lower transport costs will further attract the logistics cluster of enterprises, thereby forming a virtuous circle. In addition to the transportation advantages, logistics clusters, rooted in the ability to share assets more easily, serve customers better and allow for better adjustment to business volume [42], offer other advantages, including shared workforce, infrastructure and information. Both aldermen and public administration employees acknowledge that spatial concentration of logistics firms in logistics concentration areas can be beneficial for society at large [45]. Sheffi identifies a number of strengths linked to logistics clusters. For example, most of the logistics jobs are local work, so it is not easy to be replaced by offshore work. Additionally, logistics clusters provide opportunities to train and develop skilled workforce internally. Furthermore, logistics services serve diverse industries which, as a result, are more resilient to the recession shocks [37]. Heuvel analyzes location dynamics of logistics establishments in relation to spatial clustering and finds that logistics employment spatially concentrates in particular areas, called Absolute and Relative Concentration areas by calculating the value of LQ [38]. Chhetri uses the four-digit Australian and New Zealand Standard Industrial Classification, industries "explicitly" related to logistics were identified and aggregated with respect to employment. A principal component analysis was conducted to capture the functional interdependence of inter-related industries and measures of spatial autocorrelation were also applied to identify spatial logistics employment clusters [53]. Hong confirms the existence of agglomeration economies in logistics activities. Foreign entrants prefer cities with existing concentrations of logistics firms. The mechanism may be that more logistics providers help manufactures enhance productivity, and hence increase the market demand for logistics services. The existence of agglomeration economies supports local governments' efforts to establish logistics hubs. Cities with better logistics bases will have an advantage in attracting potential foreign logistics investments, and this advantage will be self-reinforcing [48]. 
The research of logistics space is based on location theory, new economic geography theory and economies of scale theory, and involves logistics, transportation, geography, economy, management and other fields. The driving force of logistics space evolution is the centripetal force and centrifugal force provided by land price, market demand, traffic accessibility, agglomeration advantages and government policies. Under the influence of centripetal force and centrifugal force, the logistics expansion and logistics accumulation cycle reciprocated (Figure 1).

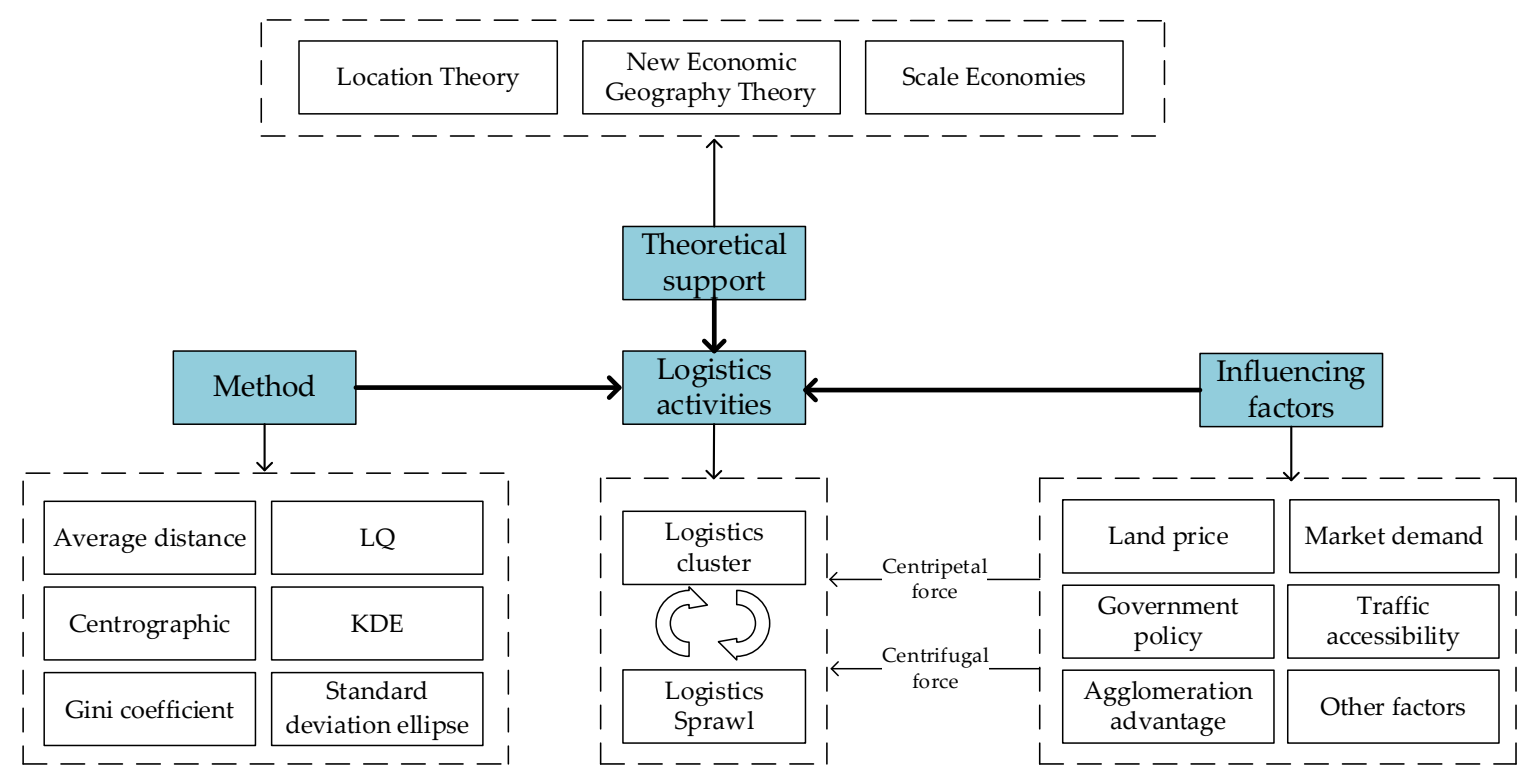

Figure 1. Research framework of logistics space.

\section{Methods and Results}

\subsection{Search Strategy}

This paper adopts several channels to identify relevant literature regarding of logistics space. Academic databases such as Web of Science, Science Direct, Springer Link and Compendex were applied to search for academic papers. Furthermore, Google Scholar was used to search for broader scope of the literature including books and conference proceedings. The starting keywords of the search included the two most widely-used phrases for the subject: "logistics space" and "freight space". Later, at least one term from each of the three categories of search terms is used to combine: (1) Logistics, freight, warehousing, distribution center; (2) Space, cluster, sprawl, distribution, locations, evolution, factors and sustainability. After the first search, a second search was made, combining with the new keywords "sustainability" and "green". The search for papers were limited to the past 15 years (2003-2018) and adapted to match the specific structure of each database. References within identified papers are also reviewed for further studies.

\subsection{Inclusion and Exclusion Criteria}

In order to make sure that each study included in the review is eligible, the studies have to: (1) be published in a peer-reviewed English journal; (2) investigate from the perspective of spatial-temporal; (3) have real and reliable data on logistics industry; (4) analyze the influence factors of distribution and evolution of logistics space.

\subsection{Search Results}

The search and retrieval process are shown in Figure 2. The numbers of papers searched from each database are 824 (Web of Science), 1206 (Science Direct), 307 (Springer Link) and 982 (Compendex). 
After removing duplicates, a total of 2813 unique records were found from four databases, of which 103 were identified following the screening of titles and abstracts. There are two reasons to exclude the invalid papers: (1) non-use data to support research; (2) research on logistics location model. After a second search, no additional articles came up that were distinct from the ones that were found in the first search run. Eventually, 71 available publications were left, 28 of which satisfied the full criteria in this review, and 44 were classified as supporting research. Figure 2 shows the search process for the papers.

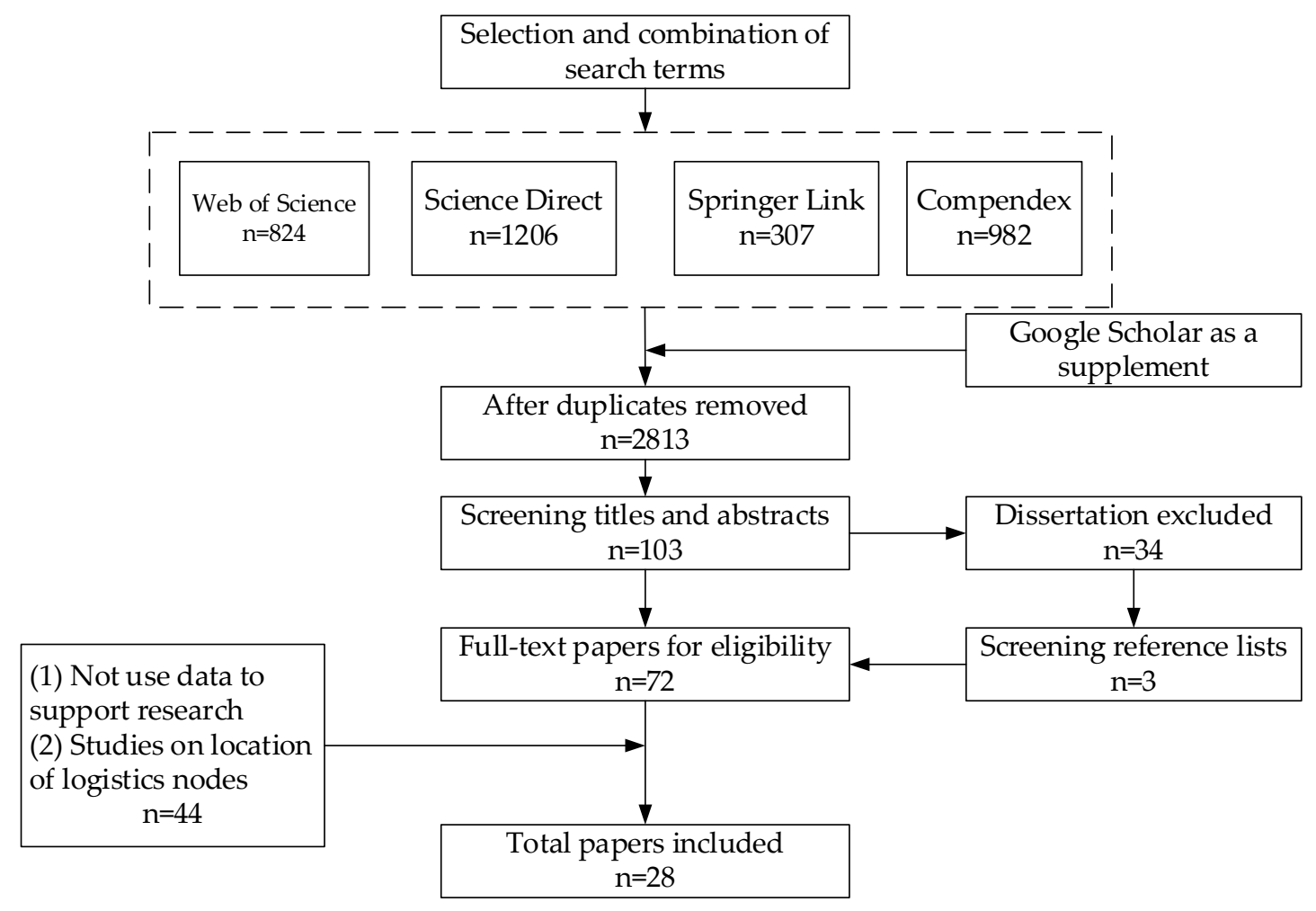

Figure 2. The flowchart of review process.

The information extracted from each of the papers mainly includes: (1) The characteristics of the papers (e.g., author, year, country and journal); (2) Data source; (3) The activities of logistics space (e.g., sprawl, cluster); (4) Research methods. The main details of 28 available papers were demonstrated as shown in Table 2. 
Table 2. Summary of the Selected Papers in this Review.

\begin{tabular}{|c|c|c|c|c|c|c|c|}
\hline Lead Author & Pub. Year & Country & Journal & Data Sources & Methodology & Activities & References \\
\hline Heitz & 2018 & Sweden & Journal of Transport Geography & Statistics Sweden & Centrographic SDE & Sprawl & [6] \\
\hline Giuliana & 2018 & US & Journal of Transport Geography & ZBP & Average distance Gini coefficient & Sprawl and cluster & [10] \\
\hline Sakai & 2017 & Japan & Journal of Transport Geography & TMFS & Kernel Density Estimation (KDE) & Sprawl & [5] \\
\hline Rolko & 2017 & Germany & Transportation Research Procedia & $\begin{array}{l}\text { Publicly and commercially } \\
\text { available sources }\end{array}$ & Descriptive statistics & / & [54] \\
\hline Kumar & 2017 & US & $\begin{array}{c}\text { Research in Transportation } \\
\text { Economics }\end{array}$ & EMSI & LQ & Cluster & [12] \\
\hline $\mathrm{Li}$ & 2017 & China & Journal of Geographical Sciences & $\begin{array}{l}\text { Tencent Online Maps } \\
\text { Platform }\end{array}$ & Average distance; KDE & / & [44] \\
\hline Holl & 2017 & Spain & Networks and Spatial Economics & SABI & Average distance & Sprawl & [11] \\
\hline $\mathrm{Xu}$ & 2017 & China & Revista de la Facultad de Ingenieria & $\begin{array}{l}\text { Zhejiang Statistical } \\
\text { Yearbook }\end{array}$ & Moran's I; LISA & Cluster & [55] \\
\hline Heitz & 2017 & $\begin{array}{c}\text { France \& } \\
\text { The Netherlands }\end{array}$ & Region & CLAP and Lisa & Centrographic; Average distance & Sprawl & [50] \\
\hline Gupta & 2017 & India & Transportation Research Procedia & Market survey & / & Sprawl & [56] \\
\hline Heitz & 2016 & France & Transportation Research Procedia & INSEE & Location mapping & Sprawl & [57] \\
\hline Woudsma & 2016 & Canada & Transportation Research Procedia & DMTI & Location mapping; Case study & Sprawl & [19] \\
\hline Todesco & 2016 & Switzerland & $\begin{array}{l}\text { 16th Swiss Transport Research } \\
\text { Conference }\end{array}$ & FSO & Average distance & Sprawl & [7] \\
\hline Heitz & 2015 & France & Transportation Research Record & INSEE & KDE; SDE; Centrographic & Sprawl & [58] \\
\hline Sakai & 2015 & Japan & Journal of Transport Geography & TMFS & $\begin{array}{l}\text { Average distance; } \\
\text { Descriptive statistics }\end{array}$ & Sprawl & [2] \\
\hline Verhetsel & 2015 & Flanders & Journal of Transport Geography & $\begin{array}{c}\text { Top } 200 \text { logistics companies } \\
\text { in Flanders }\end{array}$ & $\begin{array}{l}\text { GIS analysis; Stated } \\
\text { preference study }\end{array}$ & / & [30] \\
\hline Wang & 2015 & China & Chinese Geographical Science & $\begin{array}{l}\text { The Year Book of Chinese } \\
\text { Transportation }\end{array}$ & / & / & [59] \\
\hline Prem Chhetri & 2014 & Australia & $\begin{array}{c}\text { Journal of Physical Distribution \& } \\
\text { Logistics Management }\end{array}$ & ANZSIC & $\begin{array}{l}\text { Mapping the spatial logistics } \\
\text { employment clusters }\end{array}$ & Cluster & [53] \\
\hline Dablanc & 2014 & US & Transportation Research Record & $\begin{array}{l}\text { County Business } \\
\text { Patterns website }\end{array}$ & Location mapping & Sprawl & [51] \\
\hline
\end{tabular}


Table 2. Cont.

\begin{tabular}{|c|c|c|c|c|c|c|c|}
\hline Lead Author & Pub. Year & Country & Journal & Data Sources & Methodology & Activities & References \\
\hline Rivera & 2014 & US & $\begin{array}{c}\text { Transportation Research Part A: } \\
\text { Policy and Practice }\end{array}$ & CBP\&SUSB & LQ; HCLQ & Cluster & [37] \\
\hline $\begin{array}{l}\text { Van den } \\
\text { Heuvel }\end{array}$ & 2013 & $\begin{array}{c}\text { The } \\
\text { Netherlands }\end{array}$ & Journal of Transport Geography & Statistics Netherlands & Locational Gini coefficient & Cluster & [38] \\
\hline Raimbault & 2012 & France & $\begin{array}{l}\text { Procedia-Social and } \\
\text { Behavioral Sciences }\end{array}$ & Yellow Pages data & Location mapping & / & [22] \\
\hline Dablanc & 2012 & US & Journal of Transport Geography & The US Census Bureau & Centrographic; SDE & $\begin{array}{l}\text { Sprawl and } \\
\text { Cluster }\end{array}$ & [8] \\
\hline Olsson & 2012 & Sweden & $\begin{array}{c}\text { Procedia-Social and } \\
\text { Behavioral Sciences }\end{array}$ & $\begin{array}{c}\text { The Statistics } \\
\text { Sweden database }\end{array}$ & Location mapping & / & [60] \\
\hline Cai & 2010 & China & The Annals of Regional Science & $\begin{array}{c}\text { China City Statistical } \\
\text { Yearbook }\end{array}$ & LQ, LISA & Cluster & [61] \\
\hline Julie Cidell & 2010 & US & Journal of Transport Geography & Economic Census data & $\begin{array}{c}\text { Gini coefficients; } \\
\text { Regression analysis }\end{array}$ & Sprawl & [52] \\
\hline Bowen & 2008 & US & Journal of Transport Geography & СBР & $\begin{array}{l}\text { Location mapping; } \\
\text { Correlation analysis }\end{array}$ & / & [4] \\
\hline Hong & 2007 & China & Transportation Research Part A & The State Statistical Bureau & Correlation analysis & / & [48] \\
\hline
\end{tabular}




\subsection{Literature Overview}

\subsubsection{Classification Based on Time}

As Table 3 clearly demonstrates, the study of the yearly distribution of articles shows the emphasis on logistics space has gradually increased after 2013. Nearly half of the articles have been published after year 2016, and 75\% have been published after 2013. Traffic accessibility, infrastructure, the availability and cost of land, market size, labor quality, agglomeration economies as well as government incentives are the most important factors in the location of logistics facilities and firms [28]. The locations with these conditions are constrained by the availability of industrial land that are offered by local government. It's increasingly difficult for logistics firms and logistics facilities to require large amounts of land. A more comprehensive research of logistics space will ensure the efficient operation of logistics activities and avoid waste of resources. So, papers on logistics space have been increasing year by year, especially in 2017. Table 3 gives the distribution of papers over the years.

Table 3. Distribution of papers through the years.

\begin{tabular}{ccc}
\hline Years & Number of Articles & $\%$ \\
\hline $2016-2018$ & 13 & 46 \\
$2013-2015$ & 8 & 29 \\
$2010-2012$ & 5 & 18 \\
$2007-2009$ & 2 & 7 \\
\hline
\end{tabular}

\subsubsection{Classification in Terms of Country}

According to the information screened from these 28 research papers, the research on logistics space mainly focuses on developed countries, such as the United States $(n=7)$, France $(n=5)$, Japan $(n=2)$, The Netherlands $(n=2)$, Sweden $(n=2)$, Flanders $(n=1)$, Germany $(n=1)$, Canada $(n=1)$, Switzerland $(n=1)$, Australia $(n=1)$, Spain $(n=1)$. The remaining three researches are also in developed areas of developing countries, such as China $(n=5)$, India $(n=1)$. Figure 3 shows the countries to which 28 literatures researching logistics space belongs. These countries are located in Europe, North America, Asia, and Oceania. They have long coastlines, developed ports, and advanced logistics facilities. The close relationship between economic development and logistics development is obvious. On the one hand, with full utilization of the economic strength, developed areas provides a solid base to develop logistics, bolstering logistic infrastructure development and industrial scales, improving logistic service quality, and keeping the rapid growth of the whole industry. On the other hand, logistics industry, as a new "engine" driving the fast development of national economy, can reduce the market transaction cost and integrate different resources of logistics industry, which then provides guarantee for the improvement of regional economic capacity [15].

Table 4 shows the basic situation of some of the study regions in the 28 papers, including population, area, population density, and the change in the number of logistics facilities. We have found that research on logistics space is mainly concentrated in densely populated regions, and that these regions have perfect transportation infrastructure, proximity to ports and airports, and dense multimodal transport networks, which provide a good environment for the development of logistics. For example: Los Angeles has the largest container seaport complex in the United States [10]. Tokyo Metropolis has developed highways, and the seaport and airport gather a lot of traditional industries [5]. High population density represents high logistics demand. In the conventional mode, population is an important driving force for location of logistics activities [62]. In addition to Zurich and Randstad, there has been a significant increase in the number of logistics facilities in other regions. It was particularly noticed that there has been an inverse increase in the number of logistics facilities in the Tokyo area because small facilities near the city center have been replaced by large logistics facilities in the suburbs [5]. 

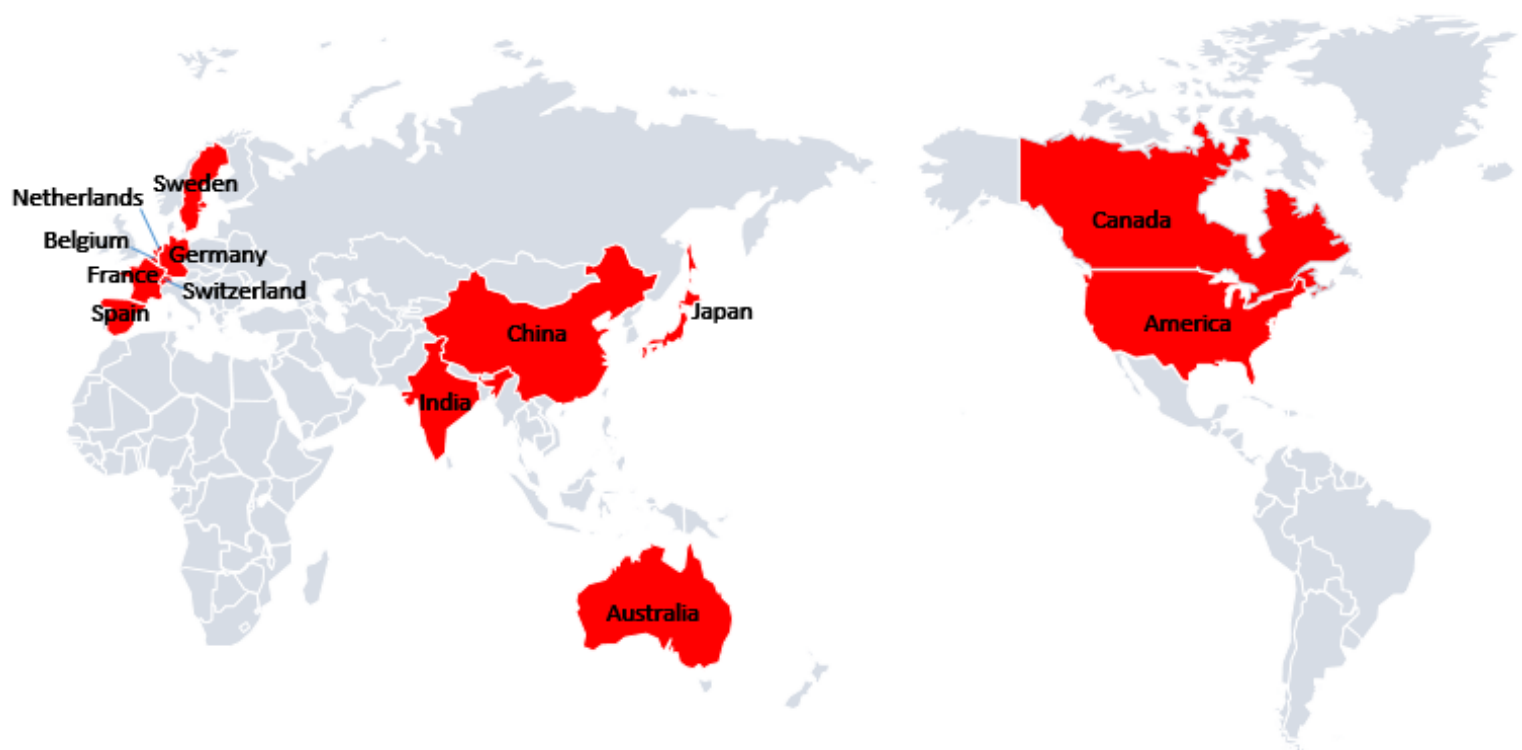

Figure 3. The countries to which 28 literatures researching logistics space belongs.

Table 4. The basic situation of study regions.

\begin{tabular}{|c|c|c|c|c|c|}
\hline Regions & $\begin{array}{l}\text { Population } \\
\text { (Million) }\end{array}$ & Area $\left(\mathrm{km}^{2}\right)$ & $\begin{array}{c}\text { Population } \\
\text { Density } \\
\text { (Inhabitants } / \mathrm{km}^{2} \text { ) }\end{array}$ & $\begin{array}{c}\text { Change in Number } \\
\text { of Logistics } \\
\text { Facilities }\end{array}$ & References \\
\hline Gothenburg metropolitan area & 0.973 & 3695 & 263.3 & $+56.8 \%$ & [6] \\
\hline Västra Götaland County & 1.615 & 22,752 & 71.0 & $+49.4 \%$ & [6] \\
\hline Los Angeles metropolitan area & 1.790 & 12,561 & 142.5 & $+29 \%$ & [10] \\
\hline Tokyo metropolitan Area & 3.700 & 15,950 & 231.9 & $-24 \%$ & {$[2,5]$} \\
\hline Beijing & 2.172 & 16,410 & 132.4 & / & [44] \\
\hline Randstad & 8.500 & 8357 & 1017.1 & $+1 \%$ & [50] \\
\hline Paris & 11.900 & 12,012 & 990.7 & $+34 \%$ & [50] \\
\hline Greater Toronto Area & 6.000 & 5904 & 1016.3 & $+38.2 \%$ & [19] \\
\hline Zurich & 0.380 & 92 & 4130.4 & $-0.1 \%$ & [7] \\
\hline North Brabant & 0.800 & 4929 & 162.3 & $+67 \%$ & [38] \\
\hline Atlanta & 5.000 & 11,204 & 446.3 & $+203 \%$ & [8] \\
\hline
\end{tabular}

\subsubsection{Classification on Data Sources}

The data sources of 28 papers mainly divided into three categories: Statistical Yearbook, network resources and logistics company sample survey data. The statistical yearbook is generally subdivided into zip codes (ZIP-CODE) for analysis. Since zip codes are relatively large spatial units, there are certain limitations [10]. The sample survey data of logistics enterprises, including the address of logistics enterprises, the number of employees, the type of logistics activities, etc., is suitable for in-depth study of logistics space. However, it also causes some limitations that sample size is small and the year of statistics is discontinuous. The development of logistics is accompanied by the production of a large amount of logistics data. The network data resources are abundant and easy to obtain, which will become an effective means of mining data. Google Earth, Tencent Map, and Amap provide data support for logistics space research. For example, Li collected 4396 logistics points of interest (POI) in Beijing based on Tencent Online Maps Platform [44]. NACE (European industry classification system) and NAICS (North American Industry Classification System) are used to identify establishments with logistics facilities in these databases. There are also other scholars who use the national standards for the classification of logistics enterprises. For example, Holl used the Spanish National Classification of Economic Activities (CNAE), and Li referred to China's "Logistics Enterprise Classification and Evaluation Index" [11,44]. 


\subsubsection{Research Method of Logistics Space}

We have summarized the analysis method of logistics space and divided all methods into management perspective and geography perspective, as shown in Table 5 . The geography perspective mainly includes average distance method, centrographic, standard deviation ellipse and kernel density estimation. The average distance can visually show the dispersion of logistics facilities through the change of distance, so it is often used to determine the logistics expansion. Centrographic and standard deviation ellipses are ideally suited to provide resources for their cartographic representations and to visualize the scope and direction of logistics expansion. The combination of the two methods works better. Kernel density estimation is suitable for the visual expression of point distribution patterns. Management perspectives include Gini coefficient, LQ, HCLQ, Moran's I, and LISA. These methods are mainly used to measure industrial spatial concentration and industrial spatial correlation. In addition, location mapping can simply reflect the distribution of logistics space and is often used to be an analysis aid. As a computer tool that can analyze and process spatial information, GIS (Geographic Information System) is used in geography research. Shen used GIS as a platform to establish a decision-making information system for water resources management in the Zhenjiang section of the Yangtze River to analyze changes in water quality and monitor pollution sources [63]. Wei used a combination of geostatistics and GIS to study the spatial distribution of soil organic matter and its influencing factors [64]. Similarly, GIS plays an important role in the study of logistics space.

Table 5. Research method of logistics space.

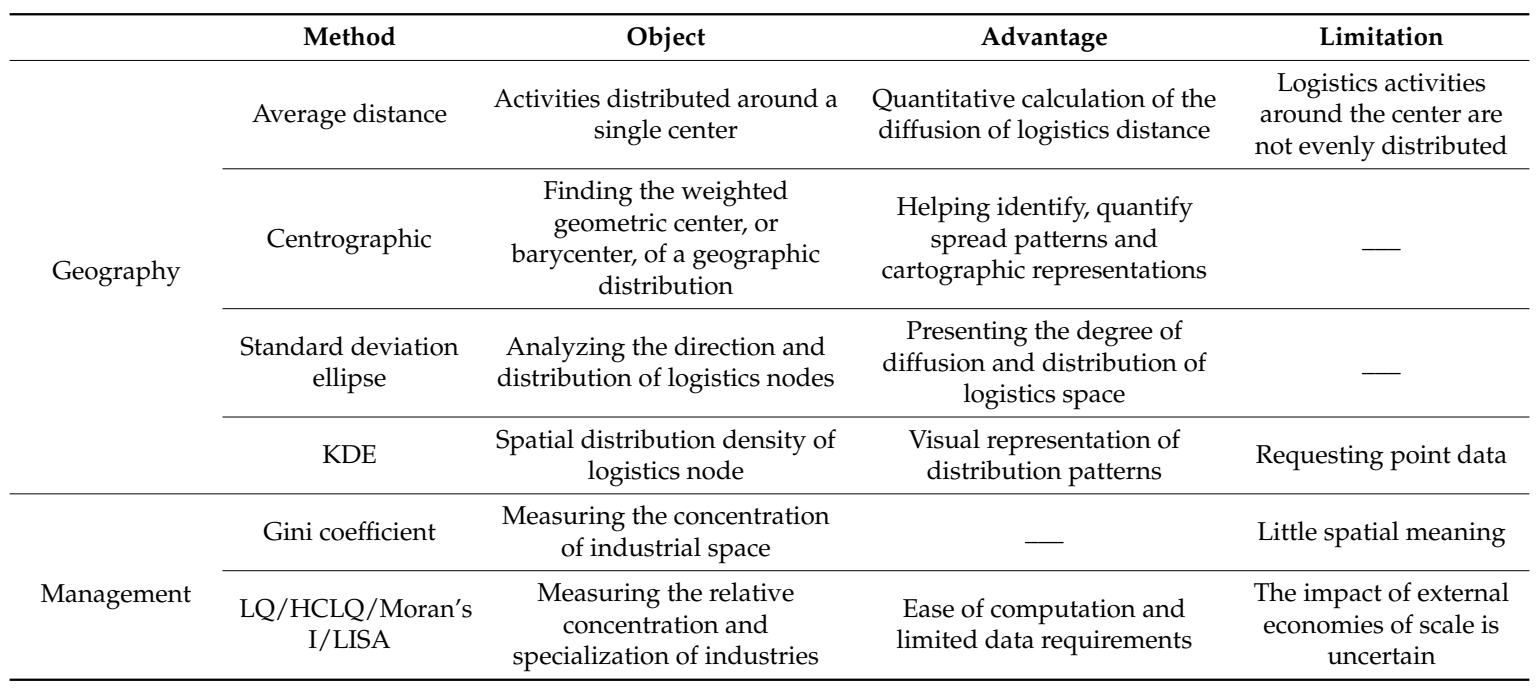

\section{Impact of Logistics Space: On Sustainability}

The purpose of logistics is to meet the needs of social production and residents' life. There are many participants in logistics system, including suppliers, manufacturers, distributors, and logistics service providers. Around logistics activities, procurement, transportation, warehousing, loading and unloading, handling, circulation processing, packaging and information are important functions. The freight transport is an important field for local sustainability strategies, since it causes severe environmental, social and economic problems in towns and regions, such as air pollution, noise emissions, infrastructure and land use demand [65]. According to the survey data, China's energy consumption of tertiary industry accounts for approximately $30 \%$ of the total energy consumption. As the main forms of the logistics industry, transportation, warehousing, and postal service account for more than $80 \%$ of energy consumption of tertiary industry [36]. Sustainability in a broader sense is a framework that stipulates that available resources of today directly and profoundly affect those of tomorrow [66]. It has attracted researchers as well as practitioners to study various aspects of sustainability. 
Combing the existing literature, we can see that most of them analyze sustainability from the perspective of logistics activities and supply chain. Logistics activities are intermediate inputs, so that the demand for logistics services derives from the demand for final goods or services [11]. The output of logistics activities has a certain impact on the environment, economy and society. According to Centobelli et al., logistics activities service is divided into four categories: transport, warehousing, logistics service and management [67]. Each service can achieve green goals and sustainable development through technological or policy means. Due to globalization, challenging market, demand uncertainty, and economic competitiveness, business organizations are under serious threat to sustain their existing supply chain. Researchers have attempted to extend the boundary of sustainable development into the area of supply chain management (SCM), to investigate sustainable supply chain management. Núñez-Cacho et al. propose that the design and incorporation of reverse logistics into SCM will allow the family company to close the cycle of resources, improving its environmental sustainability [68]. Zhang et al. propose a hierarchical structure of sustainable supply chain management and develops a multi-item measurement scale to reflect the specific management practices of sustainable supply chain management [69]. Extend the boundary of sustainable development into the area of SCM is particularly important.

The scope of logistics space involves a wide range, from the raw materials and production logistics in the manufacturing industry, to the sales logistics in the trade and circulation industry, to the reverse logistics of the final waste. From a geographical point of view, the researches on logistics space mainly focus on the following two aspects: sprawl and cluster. Dablanc's research on logistics activities in the metropolitan area of Atlanta shows that at the level of metropolitan areas, the layout of logistics facilities and logistics distribution centers is in a spatially decentralized state, while at the regional level, logistics activities show a tendency toward agglomeration of metropolitan areas [8]. Chen believes that the industrial diffusion and agglomeration are determined by the centrifugal force and the centripetal force of regional economic development. The centrifugal force is the operating cost increase of the enterprise, and the centripetal force mainly includes the external economy formed by industrial agglomeration [28]. Logistics enterprises and logistics nodes exhibit the characteristic of both co-agglomeration and spatial separation in location [44]. Prause gives three different perspectives on logistics sustainability: environmental efficiency (improving freight traffic sustainability), social efficiency (improving freight traffic acceptability) and economic efficiency (improving freight traffic efficiency) [70]. The triple bottom line standard is used to evaluate logistics space, which includes economic, environmental and social dimensions (Table 6).

\subsection{Environmental Dimension}

The development of the logistics industry can promote economic growth, but it also causes an increase in energy consumption and carbon emissions. Logistics sprawl helps to change the geography of urban freight, increase the distance traveled by trucks and the resulting emissions, and affect the commuting rate of logistics employment [9]. The increase in truck travel distance is the biggest impact of logistics sprawl. Between 2007 and 2015, the average haul distance of China's road freight transport increased by $13 \mathrm{~km}$. China's energy consumption for the logistics industry has increased by $47 \%$, reaching 383.2 million tons of standard coal in 2015. The sustainable development of logistics is restricted by decreasing energy. The energy efficiency has attracted the attention of scholars. It is very important to create energy districts, with the main objective that they are configure as platforms for the valorization of energy technological nutrients derived from biomass to supply energy and be more efficient from an environmental and economic point of view [71]. In addition, energy consumption inevitably leads to greenhouse gas emissions and air pollution. Dablanc and Rakotonarivo estimate that the expansion of logistics resulted in an increase of 15,000 tons of $\mathrm{CO}_{2}$ emissions per year in Paris area [49]. Although logistics sprawl can alleviate air pollution and noise pollution, it is harmful to the urban environment as a whole. 
Table 6. Findings on logistics space from selected articles.

\begin{tabular}{|c|c|c|c|c|c|}
\hline \multirow{2}{*}{$\begin{array}{l}\text { Lead Author } \\
\text { (Pub. Year) }\end{array}$} & \multirow{2}{*}{ References } & \multicolumn{3}{|c|}{ Dimension } & \multirow{2}{*}{ Findings } \\
\hline & & Environmental & Social & Economic & \\
\hline $\begin{array}{l}\text { Pedro Núñez-Cacho } \\
\text { (2018) }\end{array}$ & [68] & $\sqrt{ }$ & $\sqrt{ }$ & $\sqrt{ }$ & $\begin{array}{l}\text { Environmental sustainability is achieved through the interaction of these } \\
\text { subsystems and the new processes. Besides, the design and incorporation of } \\
\text { reverse logistics into SCM will allow the family company to close the cycle of } \\
\text { resources, improving its environmental sustainability. }\end{array}$ \\
\hline Minhao Zhanga (2018) & [69] & $\sqrt{ }$ & $\sqrt{ }$ & & $\begin{array}{l}\text { The research proposes a hierarchical structure of sustainable supply chain } \\
\text { management and develops a multi-item measurement scale to reflect the specific } \\
\text { management practices of sustainable supply chain management. }\end{array}$ \\
\hline Piera Centobelli (2018) & [72] & $\sqrt{ }$ & $\sqrt{ }$ & $\sqrt{ }$ & $\begin{array}{l}\text { The adoption of sustainable initiative is affected by a set of drivers and barriers } \\
\text { that have an impact on the environmental, economic and operational performance } \\
\text { of the individual firm and the supply chain. }\end{array}$ \\
\hline A. Rajeev (2017) & [73] & $\sqrt{ }$ & $\sqrt{ }$ & $\sqrt{ }$ & $\begin{array}{l}\text { Sustainable or green SCM initiatives have been adopted to reduce costs and to } \\
\text { increase efficiency, internal and external customer satisfaction, and market shares } \\
\text { and sales, resulting in more effective risk management. }\end{array}$ \\
\hline Piera Centobelli (2017) & [67] & $\sqrt{ }$ & $\sqrt{ }$ & & $\begin{array}{l}\text { Logistics service providers adopt differentiation strategies marked by a } \\
\text { combination of their various experiences, approaches and behaviors to support } \\
\text { their green practices and achieve their green aims. }\end{array}$ \\
\hline A. Mete Baydar (2017) & [66] & & $\sqrt{ }$ & $\sqrt{ }$ & $\begin{array}{l}\text { With the available work in the literature on freight villages and their impact on } \\
\text { sustainability (decreasing negative environmental impacts and increasing social } \\
\text { welfare) in specific, it is not possible to justify the potential of freight villages and } \\
\text { their promising positive impacts on sustainability such as decreasing greenhouse } \\
\text { gas emissions, } \mathrm{CO}_{2} \text { reduction, etc., and functioning as a business generator in the } \\
\text { related region they operate. }\end{array}$ \\
\hline $\begin{array}{c}\text { Zulfiquar N. Ansari } \\
\text { (2017) }\end{array}$ & [74] & $\sqrt{ }$ & $\sqrt{ }$ & $\sqrt{ }$ & $\begin{array}{l}\text { Though significant amount of research is being carried out to implement } \\
\text { sustainability concepts in industrial supply chain, but there still exist some } \\
\text { potential opportunities that need to be addressed such as (i) quantitative study in } \\
\text { sustainable SCM (ii) modeling of real life complex sustainable factors using } \\
\text { dynamic programming, goal programming, etc. }\end{array}$ \\
\hline Ye Li (2016) & [46] & $\sqrt{ }$ & & & $\begin{array}{l}\text { The road freight transportation is the key mitigation subsector, accounting for } \\
85-92 \% \text { of the total Carbon emission. For energy conservation and carbon } \\
\text { emission mitigation, logistics informatization is the most effective method. }\end{array}$ \\
\hline
\end{tabular}


Table 6. Cont

\begin{tabular}{|c|c|c|c|c|c|}
\hline \multirow{2}{*}{$\begin{array}{l}\text { Lead Author } \\
\text { (Pub. Year) }\end{array}$} & \multirow{2}{*}{ References } & \multicolumn{3}{|c|}{ Dimension } & \multirow{2}{*}{ Findings } \\
\hline & & Environmental & Social & Economic & \\
\hline $\begin{array}{l}\text { Nicole van Buren } \\
\text { (2016) }\end{array}$ & [47] & $\sqrt{ }$ & $\sqrt{ }$ & $\sqrt{ }$ & $\begin{array}{l}\text { Among the many stakeholders, a genuine enabler to implement a successful and } \\
\text { sustainable circular strategy is the logistics industry. }\end{array}$ \\
\hline Fan Xiao (2015) & [36] & $\sqrt{ }$ & & $\sqrt{ }$ & $\begin{array}{l}\text { The logistics energy intensity and carbon intensity are examined to describe the } \\
\text { relations between logistics industry and economic development. The methods of } \\
\text { optimizing energy utilization and reducing environmental impact in the logistics } \\
\text { industry are important to promote the development of green logistics systems. }\end{array}$ \\
\hline Gunnar Prause (2014) & [70] & $\sqrt{ }$ & $\sqrt{ }$ & $\sqrt{ }$ & $\begin{array}{l}\text { Logistics clusters and their performance and development represent a neglected } \\
\text { area in the academic literature. Future research should be done on coherent } \\
\text { controlling concepts of green corridor and their integrated logistics clusters in } \\
\text { order to safeguard a sustainable development. }\end{array}$ \\
\hline $\begin{array}{l}\text { Laetitia Dablanca } \\
\quad(2010)\end{array}$ & [49] & $\sqrt{ }$ & & & Logistics sprawl has an environmental and $\mathrm{CO}_{2}$ impact on the Paris region. \\
\hline Markus Hesse (1995) & [65] & $\sqrt{ }$ & $\sqrt{ }$ & $\sqrt{ }$ & $\begin{array}{l}\text { Freight transport causes severe environmental, social and economic problems in } \\
\text { towns and regions, such as air pollution, noise emissions, infrastructure and land } \\
\text { use demand. }\end{array}$ \\
\hline
\end{tabular}




\subsection{Social Dimension}

The development of logistics space has brought about great social effects, such as employment, urban traffic safety and urban geography. On the one hand, some municipalities favour logistics activities, considering that they provide industrial jobs requiring little qualifications when more traditional manufacturing jobs have disappeared from metropolitan areas. On the other hand, many municipalities reject logistics activities, because they generate noise, truck traffic and safety problems [49]. They are also accused of consuming space, with a low ratio of jobs per hectare. Frequent shipments put pressure on local traffic safety and affect the normal operation of other social activities. Freight vehicles should avoid direct conflicts with other social vehicles, and its route and time is determined by the location of logistics facilities. In addition, heavy-duty trucks will cause wear on the road surface, destroy road infrastructure, and bring serious security risks. Generally speaking, the increase in freight capacity itself may very well increase the employment level. Logistics facilities need a reasonable position to ensure the sustainable development of society.

\subsection{Economic Dimension}

Logistics clusters and their performance and development represent an important area in the academic literature. The scales of business activities are already promising, and for any commercial firm to enter such business cooperation with other firms, some measure of risk and/or cost minimization must be satisfied. Transportation costs and service advantages benefit from scale effect have led some logistics enterprises to start gathering in specific areas. The logistics agglomeration area will attract other enterprises to enter, thus forming a characteristic industrial park to drive economic growth. Cooperation and coordination among members affect economic sustainable development. The continuous development of logistics parks or cargo villages will provide more efficient logistics activities by integrating freight and increasing efficiency, thus ensuring sustainable economic development [66].

\section{Discussion}

The purpose of this literature review is to summarize and critically assess the current papers on logistics space. To the best of our knowledge, this may be the first time to comprehensively evaluate the research status of logistics space from the perspectives of logistics agglomeration and logistics diffusion.

\subsection{The Process of Logistics Space Evolution}

Cluster and sprawl are two typical distribution characteristics and development trend of spatial structure of urban logistics network. However, the evolution of spatial structure of urban logistics network is not a simple process of cluster and sprawl (suburbanization), but a more complicated one. Phase 1: Due to government policies and geographical advantages, logistics facilities is distributed from the initial scattered distribution to the agglomeration. At this time, logistics companies are located in the central area of the city; Phase 2: With the advantages of agglomeration and economies of scale, these companies have continued to develop themselves. When its concentration reaches saturation, the logistics industry begins to transfer from the agglomeration center to the port, industrial park, and logistics park along the traffic channel; Phase 3: The logistics facilities that are concentrated in the city center's central area have shifted outward as the city has spread. Some transportation areas are well-positioned and industrially developed areas will become new logistics clusters [75]. At this point, the formation of the spatial pattern of urban logistics is the result of repeated exercise of logistics sprawl and logistics clusters. (Figure 4 shows the three phases of the evolution of logistics space). 


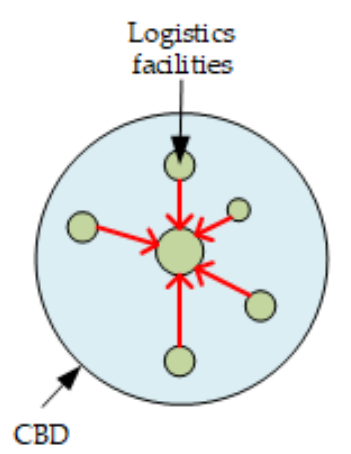

Phase 1

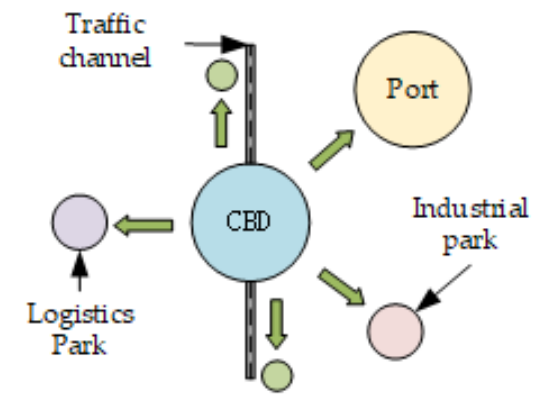

Phase 2

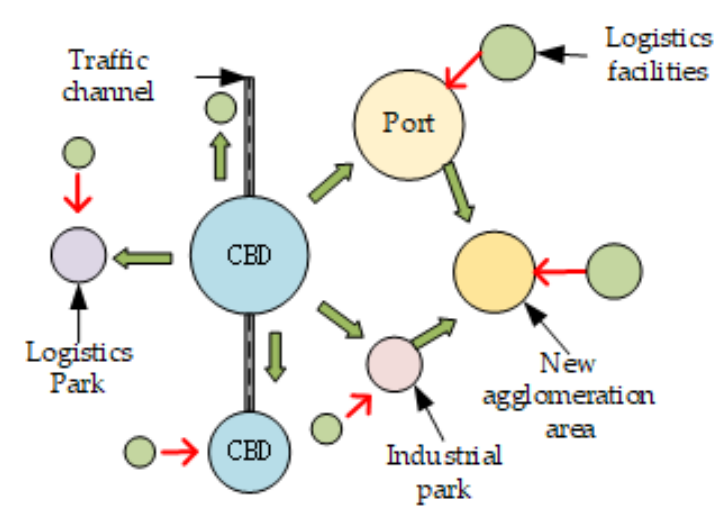

Phase 3

Figure 4. The progress of the evolution of logistics space.

\subsection{Factor Issues}

This paper extracts five factors which can best explain the evolution of logistics space: land price, traffic accessibility, market demand, agglomeration advantage and government policy. In addition, industrial structure, labor level and e-commerce logistics are also important influencing factors in the evolution of logistics space. The original development foundation of the logistics industry comes from the logistics service demand generated by the manufacturing industry, which has derivative characteristics. To select logistics company's site relies on the degree of manufacturing distribution. Because the logistics industry is a labor-intensive industry, the labor cost has an important influence on the location selection or transfer of logistics companies. The rapid development of e-commerce highlights the importance of logistics distribution and supply chain. Online retailers and logistics companies focus on improving the supply chain system and building new types of supply chain infrastructure such as distribution centers and distribution centers in the suburbs. In particular, the popularity of online retailing and logistics companies provide services to end consumers from indirect to direct services. E-commerce warehouses usually occupy a large area to meet the needs of massive commodity categories and one-stop storage. For example: Suning's "Super Cloud Warehouse" and Jingdong's "Asian One." Although the automated warehouse system and loft racking system make full use of the storage space, its floor space still exceeds $100,000 \mathrm{~m}^{2}$, and in 2019 , the total storage area of Suning has reached $12 \mathrm{~km}^{2}$. In order to save operating costs, many e-commerce companies have gradually migrated to the suburbs [76]. The Internet of Things and 5G will promote real-time information-driven logistics activities to optimize logistics resource allocation, reduce energy consumption and distribution distance, and achieve sustainable logistics. Different types of logistics companies are affected by different factors. Warehousing and transportation logistics companies have high requirements for land rent and transportation, while logistics companies engaged in 
information management tend to be densely populated. This article makes a qualitative assessment of the influencing factors of logistics space. If there is more data to support, quantitative methods can be used to further measure the influence degree of each factor so that to logistics space, a deep understanding of its evolutionary mechanism can be gained.

\subsection{Recommendations for Logistics Space Planning}

In order to ensure the reasonable distribution of logistics space and determine the optimal location, scale and type of logistics facility activities, a sustainable development blueprint must be planned. First of all, the government should formulate a strategy for the sustainable use of logistics land, make full and reasonable use of land resources, increase land utilization, and curb the idleness and waste of land. Thus the priority is to integrate existing logistics facilities, achieve intensive use of land, and minimize land use conflicts. What's more, to tap the potential of land use and develop new logistics land is necessary. Governments and enterprises should increase the construction of automated warehouses and develop underground logistics systems-a new logistics model that promotes sustainable urban development. In addition, at the required time, the production mode of the desired product is produced in the required quantity. Just-in-time production eliminates inventory, optimizes production logistics, and reduces dependence on storage land. Secondly, to improve the mobility of logistics activities is an important way, including increasing the construction of traffic network and port intermodal transport, and improving the transit transport system. Good traffic accessibility facilitates the organization of transportation routes for logistics activities, reduces transportation distances, and improves the logistics efficiency of enterprises. Finally, the government should promote the joint development of the logistics industry and the manufacturing industry. The spatial planning of the manufacturing industry can effectively guide the transfer of the logistics industry and achieve a balance between supply and demand in the logistics space. The joint development of the manufacturing industry and the logistics industry is not only an important means of adjusting the industrial structure and transforming economic growth, but also a common requirement and an urgent need for the manufacturing and logistics industries.

\section{Conclusions and Potential Research Directions}

Some studies have confirmed that with the continuous development of economic globalization and integration, logistics geospatial space has changed. As sustainability is a new requirement for regional and urban development, logistics is becoming a new public issue for local governments. In order to limit energy consumption and greenhouse gas emissions and improve efficiency of economic development, controlling the location of logistics facilities is becoming the goal of urban space planning. This paper examines two activities of the logistics space: sprawl and cluster. It is found that logistics sprawl and cluster are promoting the integration of urban logistics facilities resources and the division of logistics functional areas. When planning the location of logistics nodes and enterprises, urban planners and business decision makers should fully consider the impact of land rent, traffic accessibility, market demand, agglomeration advantages, and government policies. And should also pay attention to the economic and social problems brought about by logistics, such as energy shortages, environmental pollution and so on. As the pace of economic activities has accelerated, the requirements for logistics efficiency have become higher and higher. It will be critical to allocate logistics facilities in a geographical space and coordinate logistics needs and supply of logistics services. The sustainable logistics development strategy and innovative logistics operation model are urgently needed to promote the rapid development of logistics. Research on logistics space has achieved preliminary results, but in terms of a complete academic system, existing research has weaknesses in the following areas:

(1) Theoretical research. The theoretical support of logistics space mainly comes from the theory of industrial agglomeration and the theory of economies of scale in economics, and the location 
theory of geography. The breadth and depth of theoretical research is limited, and a complete theoretical system has not yet been established.

(2) Method research. The research method for logistics space is through the processing of data, calculation of industrial agglomeration index and the use of ArcGIS software to display the spatial distribution of logistics facilities on the map. Due to the use of previous data, there is a time lag in the conclusion of the study. Future research can use forecasting models to predict the evolution of logistics space based on the development trend of logistics and the government's future plans.

(3) Data mining. The acceleration of the logistics information process and the continuous development of a large amount of logistics information include not only the location data of logistics facilities but also the spatial data of freight movement. The rational use of these data to study the distribution and evolution of logistics space from the perspective of macro and micro, abstract and concrete, has important theoretical and practical significance. Limited to the complexity of the logistics industry and lack of real and reliable data, it has certain deviations from the distribution and evolution of logistics space. Future research should strengthen the collection and screening of logistics data.

(4) Practical application. Due to the time lag of data, the research results can only provide experience guidance for the evolution of logistics space. Research mainly focuses on qualitative research, and it is difficult to provide accurate guidance for government planners and business decision makers.

Author Contributions: M.H. and J.S. conceived the conception and collected documents. J.L. and X.W. screened eligible papers carefully given reasonable opinions; J.S. wrote the manuscript. All authors have read and approved the final manuscript.

Funding: This research was supported by "the Natural Science Foundation of Jiangsu Province", (Grants No BK20160512), "the Humanity and Social Science Youth foundation of Ministry of Education of China", (Grants No 16YJCZH027), "the Social Science Foundation of Jiangsu Province", (Grants No 15GLC004), "the National Natural Science Foundation of China", (Grant No. 71772080).

Acknowledgments: The authors thank the anonymous reviewers and members of the editorial team for their constructive comments.

Conflicts of Interest: The authors declare no conflict of interest.

\section{References}

1. Hu, Y.Y.; Cao, W.D. Location Characteristics and Formation Mechanism of Logistics Space in Hefei City. Reg. Res. Dev. 2016, 35, 58-63. (In Chinese)

2. Sakai, T.; Kawamura, K. Locational dynamics of logistics facilities: Evidence from Tokyo. J. Transp. Geogr. 2015, 46, 10-19. [CrossRef]

3. Rivera, L.; Sheffi, Y. Logistics clusters: The impact of further agglomeration, training and firm size on collaboration and value added services. Int. J. Prod. Econ. 2016, 179, 285-294. [CrossRef]

4. Bowen, J.T. Moving places: The geography of warehousing in the US. J. Transp. Geogr. 2008, 16, 379-387. [CrossRef]

5. Sakai, T.; Kawamura, K. Spatial reorganization of urban logistics system and its impacts: Case of Tokyo. J. Transp. Geogr. 2017, 60, 110-118. [CrossRef]

6. Heitz, A.; Dablanc, L. Spatial patterns of logistics facilities in Gothenburg, Sweden. J. Transp. Geogr. 2018. [CrossRef]

7. Todesco, P.; Weidmann, U. Logistics Sprawl in the Region Zurich. In Proceedings of the 16th Swiss Transport Research Conference, Ascona, Switzerland, 18-20 May 2016.

8. Dablanc, L.; Ross, C. Atlanta: A mega logistics center in the Piedmont Atlantic Megaregion (PAM). J. Transp. Geogr. 2012, 24, 432-442. [CrossRef]

9. Aljohani, K.; Thompson, R.G. Impacts of logistics sprawl on the urban environment and logistics: Taxonomy and review of literature. J. Transp. Geogr. 2016, 57, 255-263. [CrossRef]

10. Giuliano, G.; Kang, S. Spatial dynamics of the logistics industry: Evidence from California. J. Transp. Geogr. 2018, 66, 248-258. [CrossRef] 
11. Holl, A.; Mariotti, I. The Geography of Logistics Firm Location: The Role of Accessibility. Netw. Spat. Econ. 2017, 18, 1-25. [CrossRef]

12. Kumar, I.; Zhalnin, A. Transportation and logistics cluster competitive advantages in the U.S. regions: A cross-sectional and spatio-temporal analysis. Res. Transp. Econ. 2017, 61, 25-36. [CrossRef]

13. Hesse, M.; Rodrigue, J. The transport geography of logistics and freight distribution. J. Transp. Geogr. 2004, 12, 171-184. [CrossRef]

14. He, B.; Fu, Q. Evaluation of logistics industry development and analysis of its spatial agglomeration. Rev. Fac. Ing. 2017, 32, 15-24.

15. Lan, S.; Yang, C. Data analysis for metropolitan economic and logistics development. Adv. Eng. Inform. 2017, 32, 66-76. [CrossRef]

16. Rodrigue, J. The Thruport concept and transmodal rail freight distribution in North America. J. Transp. Geogr. 2008, 16, 233-246. [CrossRef]

17. Christopher, M. Logistics \& Supply Chain Management; FT/Prentice Hall: London, UK, 2003.

18. Woudsma, C.; Jensen, J.F. Accessibility and Freight: Transportation and Land Use-Exploring Spatial-Temporal Dimensions; Levinson, D.M., Krizek, K.J., Eds.; Emerald Group Publishing Limited: Bingley, UK, 2005; pp. 267-295.

19. Woudsma, C.; Jakubicek, P.; Dablanc, L. Logistics Sprawl in North America: Methodological Issues and a Case Study in Toronto. Transp. Res. Procedia 2016, 12, 474-488. [CrossRef]

20. Department of Urban Social and Economic Investigation, National Bureau of Statistics. Statistical Yearbook of China's Urban Construction; China Planning Press: Beijing, China, 2007.

21. Hesse, M. Land for logistics: Locational dynamics, real estate markets and political regulation of regional distribution complexes. Tijdschr. Econ. Soc. Geogr. 2004, 95, 162-173. [CrossRef]

22. Raimbault, N.; Andriankaja, D.; Paffoni, E. Understanding the Diversity of Logistics Facilities in the Paris Region. Procedia Soc. Behav. Sci. 2012, 39, 543-555. [CrossRef]

23. McKinnon, A. The present and future land requirements of logistical activities. Land Use Policy 2009, 26, S293-S301. [CrossRef]

24. Atieh, A.M.; Kaylani, H.; Al-abdallat, Y.; Qaderi, A.; Ghoul, L.; Jaradat, L.; Hdairis, I. Performance Improvement of Inventory Management System Processes by an Automated Warehouse Management System. Procedia CIRP 2016, 41, 568-572. [CrossRef]

25. Qin, L.; Liu, K. Research on Evolution Mechanism of Urban Logistics Spatial Structure. China's Circ. Econ. 2011, 30-35. (In Chinese) [CrossRef]

26. Wagner, T. Regional traffic impacts of logistics-related land use. Transp. Policy 2010, 17, 224-229. [CrossRef]

27. Tian, L.; Liang, Y.; Zhang, B. Measuring residential and industrial land use mix in the peri-urban areas of China. Land Use Policy 2017, 69, 427-438. [CrossRef]

28. Chen, W.; Shen, Y.; Wang, Y.; Wu, Q. How do industrial land price variations affect industrial diffusion? Evidence from a spatial analysis of China. Land Use Policy 2018, 71, 384-394. [CrossRef]

29. Allen, J.; Browne, M.; Cherrett, T. Investigating relationships between road freight transport, facility location, logistics management and urban form. J. Transp. Geogr. 2012, 24, 45-57. [CrossRef]

30. Verhetsel, A.; Kessels, R.; Goos, P.; Zijlstra, T.; Blomme, N.; Cant, J. Location of logistics companies: A stated preference study to disentangle the impact of accessibility. J. Transp. Geogr. 2015, 42, 110-121. [CrossRef]

31. Hansen, W.G. How Accessibility Shapes Land Use. J. Am. Inst. Planners 1959, 25, 73-76. [CrossRef]

32. Ng, C.P.; Law, T.H.; Wong, S.V.; Kulanthayan, S. Relative improvements in road mobility as compared to improvements in road accessibility and economic growth: A cross-country analysis. Transp. Policy 2017, 60, 24-33. [CrossRef]

33. Hong, J.; Chu, Z.; Wang, Q. Transport infrastructure and regional economic growth: Evidence from China. Transportation 2011, 38, 737-752. [CrossRef]

34. Hou, Q.; Li, S.-M. Transport infrastructure development and changing spatial accessibility in the Greater Pearl River Delta, China, 1990-2020. J. Transp. Geogr. 2011, 19, 1350-1360. [CrossRef]

35. Van den Heuvel, F.P.; Rivera, L.; van Donselaar, K.H.; de Jong, A.; Sheffi, Y.; de Langen, P.W.; Fransoo, J.C. Relationship between freight accessibility and logistics employment in US counties. Transp. Res. Part A Policy Pract. 2014, 59, 91-105. [CrossRef]

36. Xiao, F.; Hu, Z.-H.; Wang, K.-X.; Fu, P.-H. Spatial Distribution of Energy Consumption and Carbon Emission of Regional Logistics. Sustainability 2015, 7, 9140-9159. [CrossRef] 
37. Rivera, L.; Sheffi, Y.; Welsch, R. Logistics agglomeration in the US. Transp. Res. Part A Policy Pract. 2014, 59, 222-238. [CrossRef]

38. Van den Heuvel, F.P.; de Langen, P.W.; van Donselaar, K.H.; Fransoo, J.C. Spatial concentration and location dynamics in logistics: The case of a Dutch province. J. Transp. Geogr. 2013, 28, 39-48. [CrossRef]

39. Liu, B.Z.; Lin, T. Research on the Relationship between Logistics Outsourcing and Productivity in Manufacturing Industry. Chin. Ind. Econ. 2010, 9, 67-77. (In Chinese)

40. Nuzzolo, A.; Comi, A. City Logistics Planning: Demand Modelling Requirements for Direct Effect Forecasting. Procedia Soc. Behav. Sci. 2014, 125, 239-250. [CrossRef]

41. Chung, T.W. A Study on Logistics Cluster Competitiveness among Asia Main Countries using the Porter's Diamond Model. Asian J. Ship. Logist. 2016, 32, 257-264. [CrossRef]

42. Sheffi, Y. Logistics-Intensive Clusters: Global Competitiveness and Regional Growth. In Handbook of Global Logistics: Transportation in International Supply Chains; Bookbinder, J.H., Ed.; Springer: New York, NY, USA, 2013; pp. 463-500.

43. Qian, Q.L.; Chen, Y.B. The spatial layout characteristics of logistics enterprises in Guangzhou and its influencing factors. Geogr. Res. 2011, 30, 1254-1261. (In Chinese)

44. Guoqi, L.; Fengjun, J. Location characteristics and differentiation mechanism of logistics nodes and logistics enterprises based on points of interest (POI): A case study of Beijing. J. Geogr. Sci. 2017, 27, 879-896. [CrossRef]

45. Van den Heuvel, F.P.; de Langen, P.W.; van Donselaar, K.H.; Fransoo, J.C. Regional logistics land allocation policies: Stimulating spatial concentration of logistics firms. Transp. Policy 2013, 30, 275-282. [CrossRef]

46. Li, Y.; Bao, L.; Li, W.; Deng, H. Inventory and Policy Reduction Potential of Greenhouse Gas and Pollutant Emissions of Road Transportation Industry in China. Sustainability 2016, 8, 1218. [CrossRef]

47. Van Buren, N.; Demmers, M.; van der Heijden, R.; Witlox, F. Towards a Circular Economy: The Role of Dutch Logistics Industries and Governments. Sustainability 2016, 8, 647. [CrossRef]

48. Hong, J. Transport and the location of foreign logistics firms: The Chinese experience. Transp. Res. Part A: Policy Pract. 2007, 41, 597-609. [CrossRef]

49. Dablanc, L.; Rakotonarivo, D. The impacts of logistics sprawl: How does the location of parcel transport terminals affect the energy efficiency of goods' movements in Paris and what can we do about it? Procedia Soc. Behav. Sci. 2010, 2, 6087-6096. [CrossRef]

50. Heitz, A.; Dablanc, L.; Tavasszy, L.A. Logistics sprawl in monocentric and polycentric metropolitan areas: The cases of Paris, France, and the Randstad, The Netherlands. Region 2017, 4, 93-107. [CrossRef]

51. Dablanc, L.; Ogilvie, S.; Goodchild, A. Logistics Sprawl: Differential Warehousing Development Patterns in Los Angeles, California, and Seattle, Washington. Transp. Res. Rec. 2014, 2410, 105-112. [CrossRef]

52. Cidell, J. Concentration and decentralization: The new geography of freight distribution in US metropolitan areas. J. Transp. Geogr. 2010, 18, 363-371. [CrossRef]

53. Chhetr, P.; Butcher, T.; Corbitt, B. Characterising Spatial Logistics Employment Clusters. Int. J. Phys. Distrib. Logist. Manag. 2014, 44, 221-241. [CrossRef]

54. Rolko, K.; Friedrich, H. Locations of Logistics Service Providers in Germany-The basis for a new freight transport generation model. Transp. Res. Procedia 2017, 25, 1061-1074. [CrossRef]

55. Xu, Y.; Chen, S. Study on the time-spatial disparity and dynamic mechanism of logistics development of Zhejiang. Rev. Fac. Ing. 2017, 32, 775-783.

56. Gupta, S. Logistics Sprawl in Timber Markets and its Impact on Freight Distribution Patterns in Metropolitan City of Delhi, India. Transp. Res. Procedia 2017, 25, 965-977. [CrossRef]

57. Heitz, A.; Beziat, A. The Parcel Industry in the Spatial Organization of Logistics Activities in the Paris Region: Inherited Spatial Patterns and Innovations in Urban Logistics Systems. Transp. Res. Procedia 2016, 12, 812-824. [CrossRef]

58. Heitz, A.; Dablanc, L. Logistics spatial patterns in Paris: The rise of the Paris Basin as a logistics megaregion. Transp. Res. Rec. J. Transp. Res. Board 2015, 2477, 76-84. [CrossRef]

59. Wang, C.J.; César, D. Port Integration in China: Temporal Pathways, Spatial Patterns and Dynamics. Chin. Geogr. Sci. 2015, 25, 612-628. [CrossRef]

60. Olsson, J.; Woxenius, J. Location of Freight Consolidation Centres Serving the City and Its Surroundings. Procedia Soc. Behav. Sci. 2012, 39, 293-306. [CrossRef] 
61. Jing, N.; Cai, W. Analysis on the spatial distribution of logistics industry in the developed East Coast Area in China. Ann. Reg. Sci. 2010, 45, 331-350. [CrossRef]

62. McKinnon, A.C. The development of warehousing in England. Geoforum 1983, 14, 389-399. [CrossRef]

63. Shen, Y.J.; Zheng, M. GIS-based water resources management decision system. Drain. Irrig. Mach. 2004, 22, 34-38. (In Chinese)

64. Wei, X.; Zhou, B.B. Influence of channel lining on soil organic matter and its spatial variability in the Huihui Canal Irrigation District. J. Drain. Irrig. Mach. Eng. 2017, 35, 222-227. (In Chinese)

65. Hesse, M. Urban space and logistics: On the road to sustainability? World Transp. Policy Pract. 1995, 4, $39-45$. [CrossRef]

66. Baydar, A.M.; Süral, H. Freight villages: A literature review from the sustainability and societal equity perspective. J. Clean. Prod. 2017, 167, 1208-1221. [CrossRef]

67. Centobelli, P.; Cerchione, R.; Esposito, E. Developing the $\mathrm{WH}^{2}$ framework for environmental sustainability in logistics service providers: A taxonomy of green initiatives. J. Clean. Prod. 2017, 165, 1063-1077. [CrossRef]

68. Nú Ez-Cacho, P.; Molina-Moreno, V.; Corpas-Iglesias, F.A.; Cortés-García, F.J. Family Businesses Transitioning to a Circular Economy Model: The Case of "Mercadona". Sustainability 2018, 10, 538. [CrossRef]

69. Zhang, M.; Tse, Y.K.; Doherty, B.; Li, S.; Akhtar, P. Sustainable supply chain management: Confirmation of a higher-order model. Resour. Conserv. Recycl. 2018, 128, 206-221. [CrossRef]

70. Prause, G. Sustainable development of logistics clusters in green transport corridors. J. Secur. Sustain. Issues 2014, 4, 59-68. [CrossRef]

71. Molina-Moreno, V.; Utrilla, P.N.C.; Cortés-García, F.J.; Peña-García, A. The Use of Led Technology and Biomass to Power Public Lighting in a Local Context: The Case of Baeza (Spain). Energies 2018, 11, 1783. [CrossRef]

72. Centobelli, P.; Cerchione, R. Environmental Sustainability and Energy-Efficient Supply Chain Management: A Review of Research Trends and Proposed Guidelines. Energies 2018, 11, 275. [CrossRef]

73. Rajeev, A.; Pati, R.K.; Padhi, S.S.; Govindan, K. Evolution of sustainability in supply chain management: A literature review. J. Clean. Prod. 2017, 162, 299-314. [CrossRef]

74. Ansari, Z.N.; Kant, R. A state-of-art literature review reflecting 15 years of focus on sustainable supply chain management. J. Clean. Prod. 2017, 142, 2524-2543. [CrossRef]

75. Qin, L. Research on the Characteristics and Evolutionary Theory of Urban Logistics Spatial Structure; Beijing Jiaotong University: Beijing, China, 2012. (In Chinese)

76. Xiao, Z.P.; Wang, Y.X. How does online retail affect the spread of urban logistics space: Taking Shenzhen as an example. City Obs. 2017, 1, 62-72. (In Chinese) 